\title{
E NÃO TEM LINHAS TUA PALMA: ESQUECER PARA PODER LEMBRAR
}

\author{
Leda Verdiani Tfouni
}

RESUMO: My intention with this paper is to show to the reader that, contrary of other works which try to present memory as presence and positivity, that is, in the form of remembrances and stored facts, this issue can be discussed under a different and opposite perspective, namely, memory as forgetfulness, necessary and involuntary forgetfulness, which is caused by the action of ideology (that is, of unconscious). Departing from this point, I will stress the role of history in the constitution and functioning of memory, and I will approach this question from the point of view of a double interrelated matrix which will be shown to be the real of history side by side with the action of interdiscourse and of the archive (here, in Pêcheux's sense, of those things which ought to be known).

PALAVRAS-CHAVE: memória, história, inconsciente, real, implícito, interdiscurso, enunciação, retroação.

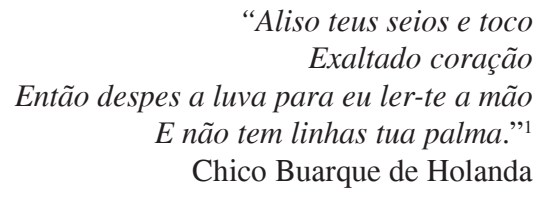

Leda Verdiani Tfouni é professora da Universidade Estadual de São Paulo (Ribeirão Preto). ${ }^{1}$ Chico Buarque de Holanda, "Sonhos, sonhos são", do CD As cidades. 
Chico Buarque, poeta-psicanalista-lingüista, estabelece nesses parcos versos, ao mesmo tempo, o modo de funcionamento da memória enquanto construto e também a forma como ela atua nos sujeitos, produzindo um efeito de presença (pressentimento?)/apagamento (dissolução?) de lembranças, eventos, pré-construídos.

Com efeito, o autor estabelece essa relação entre a busca levada a efeito pelo sujeito de algo que ele crê "estar lá", e a experiência de não encontrar o que procura, ou pensa procurar.

A luva, que encobre a mão, na verdade não encobre nada, visto que "não tem linhas tua palma". Porém, se algo se procura, e se é esperado que algo esteja lá desde sempre, como, então, explicar essa expectativa do sujeito, esse engodo de que ele é vítima? Trata-se de pura alucinação? Fantasia? O que fala nesse sistema de busca na memória que não permite que o sujeito encontre aquilo, mas outra coisa em seu lugar; algo deslocado, uma espécie de anti-objeto?

Ou, por um outro ângulo, que desejo é esse, sempre insaciável, que leva o sujeito a remexer e revirar em "sua memória" algo que nunca encontra em sua essência, mas que retorna sempre, porém deformado, modificado?

Estas são questões que se colocam como enigma para o analista que pretende escrever sobre a memória de um ponto de vista que desloque as colocações das ciências sociais e cognitivistas a respeito. Nestas duas perspectivas científicas, reencontramos aquilo que a Análise do Discurso e a Psicanálise contestam: um sujeito explicado por regras gerais, uniformizantes, sejam essas regras decorrentes da estrutura social, sejam elas decorrentes do funcionamento da "mente" (ou "inteligência", ou qualquer outro termo que procure colocar internamente ao próprio sujeito a explicação para o seu "comportamento").

Com efeito, quer se postule um sujeito consciente que é capaz de lembrar, por exemplo, "7 mais ou menos 2 dígitos" ou unidades (à maneira cognitivista); quer se postule um sujeito que se "lembra" de "fatos" históricos com maior ou menor clareza, de acordo com a "importância" social desses fatos (como faz a sociologia, por exemplo) em ambos os casos temos que a memória é estudada muito mais no sentido de "lembrança", "recordação", do que no sentido de "esquecimento", "recalque". Nessas perspectivas, a memória é um depósito de lembranças, que podem ser recordadas por uma vontade do sujeito. Assim, aquilo que não está lá, mas lateja na contingência do real, seja por esquecimento, seja por um impedimento absoluto, é ignorado, muito ao modo do trabalho das ciências positivistas e/ou racionalistas.

Quero, neste momento, colocar para o leitor que, ao contrário desses trabalhos que procuram apresentar a memória como presença e 
positividade, ou seja, sob a forma de lembranças, de fatos armazenados, minha intenção aqui é discutir uma visão oposta, qual seja: a memória como esquecimento, necessário e involuntário, provocado pela ação do recalque e da ideologia (portanto, do inconsciente). A partir daí, privilegiarei o papel da história na constituição e funcionamento da memória, e irei abordar essa questão dentro de uma matriz dupla inter-relacionada, ou seja, o real da história e a constituição do interdiscurso e do arquivo (no sentido de PÊCHEUX (1997) "das coisas a saber").

Inicio afirmando que é impossível falar de memória e história sem falar de implícito. Não no sentido da lógica, para quem implícito é o nome que se dá àquelas proposições que não são expressas, mas que vêm junto com o dito, e que podem ser deduzidas logicamente de um enunciado efetivamente produzido.

Nesse sentido, retomo aqui Achard (1999), que afirma que falar do papel da memória é falar do estatuto dos implícitos. Prossegue este autor comentando que, discursivamente, “(...) o implícito trabalha então sobre a base de um imaginário que o representa como memorizado, enquanto cada discurso, ao pressupô-lo, vai fazer apelo a sua (re) construção, sob a restrição 'no vazio' de que eles respeitem as formas que permitam sua inserção por paráfrase.” (p.13)

Para Achard, a repetição, o retorno, de uma palavra (ele dá como exemplo "crescimento", em "(...) o crescimento da economia") ou seja: a previsão, como implícito, dessa palavra, ali onde ela não é formulada, só pode ser levada a efeito pelo analista enquanto hipótese, que ele levanta a partir de um inventário feito sobre as ocorrências dessa palavra "em diversos textos e diversas posições". Ou seja, é pela repetição, regida pela regularização, “(...) que a memória suposta pelo discurso é sempre reconstruída na enunciação" (p.17), o que nos permite inferir que, na proposta do autor, a memória não é algo que se origina no sujeito, mas sim que se manifesta na enunciação.

A fim de ilustrar esse processo de atualização da memória levado a efeito no processo de enunciação, e ao mesmo tempo aprofundar a questão já colocada sobre os implícitos, trago para esta discussão o mecanismo da nomeação, e retomo uma observação feita durante uma viagem que fiz saindo de Atenas em direção a Constantinopla (portanto, da Grécia para a Turquia). Como lingüista e analista, não pude deixar de tomar conhecimento do fato de que a antiga capital da Turquia (a atual, como se sabe, é Ancara) é nomeada, do lado grego, de "Constantinopla", e do lado turco de "Istambul". As duas formas lingüísticas coexistem, como se fossem sinônimas, e realmente o fato dessa dupla nomeação passa despercebido, pois está "naturalizado" na memória social (pelo trabalho da ideologia) 
para os falantes que ficam apenas no uso linguageiro do discurso. No meu caso, porém, pelo fato de ser analista, e ocupar uma posição a partir da qual é possível um estranhamento com relação à cadeia significante, pude deter-me sobre este fato e tentar analisá-lo, como farei a seguir.

Examinemos duas hipóteses explicativas para este fato. A primeira, quase ingênua hoje em dia, explicaria como co-ocorrência por sinonímia, e diria que "tanto faz" nomear a cidade Istambul ou Constantinopla, uma vez que a referência no mundo real permanece a mesma. A segunda, mais sofisticada, iria verificar que a distribuição social dos dois significantes não se dá de maneira aleatória, visto que os turcos sempre se referem à cidade como "Istambul", enquanto os gregos sempre a nomeiam como "Constantinopla", o que leva a sugerir que o uso de um ou outro nome não é casual, nem de livre escolha do sujeito. Parece haver aí, nesse processo de nomeação, algo relacionado à identidade, a ser turco ou ser grego; portanto, a algum aspecto da memória social, do interdiscurso e dos lugares enunciativos que estão disponíveis para gregos e turcos se referirem à mesma cidade. Assim, o nome "Istambul" é mais recente historicamente, e foi adotado pelos turcos quando a anterior Constantinopla passou a ser a capital do império Otomano. Constantinopla, por sua vez, era o nome que a cidade tinha quando, em poder dos romanos, era a capital do Império Romano do Oriente. Pode-se ver que a nomeação da cidade sofreu um processo de atualização, por força dos fatos históricos, e que apenas os turcos atualizaram sua memória para essa "novidade", enquanto que os gregos não o fizeram.

Pergunta-se: Por que isso ocorreu? Por livre escolha do sujeito? Por falta de conhecimento? Ou por uma resistência à nomeação nova (por parte dos gregos), tendo em vista que alterar o nome de Constantinopla para Istambul afetaria a identidade dos gregos? Ou seja, por uma resistência radical do sujeito a ser afetado pelo real da língua naquilo que esse real traz de traumático (a inscrição da história, portanto)?

Mero exercício de retórica, este desenvolvido aqui. Que nos mostra que a argumentação de Achard é insuficiente, pois se nos ativermos apenas à enunciação, a explicação não será satisfatória.

O que o autor se esqueceu de considerar é que a história, enquanto real, ou seja, enquanto luta de classes, se insere no discurso. E, nesse sentido, não iremos efetivamente analisar a questão da dupla nomeação se não considerarmos como parte dessa análise (portanto, como elemento constitutivo dos efeitos de sentido aí produzidos quando se enuncia um ou outro significante dos dois possíveis) fatores históricos tal como o fato de que os gregos são católicos -e sempre foram, desde que a Grécia se constituiu como território de nacionalidade- enquanto que os turcos são muçulmanos -e já eram, quando tomaram Constantinopla. É preciso ter em con- 
ta, também, que Constantinopla recebeu este nome a partir de Constantino, que foi o primeiro imperador romano convertido ao catolicismo. Assim, o significante guarda as marcas de sua passagem por lugares da história, e esta, por sua vez, aí se inscreve na forma de uma memória aderente, que se atualiza à revelia do sujeito (inconscientemente) no momento da formulação, colocando os sujeitos em uma ou outra das duas religiões - e posições - antagônicas e em luta. Este é o papel do interdiscurso, e da ideologia.

Continuando a análise, é preciso considerar também que a palavra Istambul é uma corruptela de uma perífrase que em grego significa "Vou para a cidade" ("Eis Ten Polis"). O nome foi adotado pelos turcos otomanos após a derrocada do Império Romano do Oriente (cuja capital era Constantinopla), por volta de 1453. O que temos aí, enroscado na metáfora do cristianismo (em Constantinopla) e na metonímia do islamismo (Istambul) é a atuação de algo diferente de um implícito, visto que nenhuma dedução puramente enunciativa levaria em consideração a memória política envolvida aí. Nem explicaria como uma perífrase ("vou para a cidade") se transforma, e passa a funcionar, na língua, como nome próprio (Istambul). Fica difícil, diante destas colocações, sustentar a posição de que a memória se atualiza no momento da enunciação. Assim, temos aí agindo no ato da enunciação, não apenas implícitos, enquanto ausências que retornam, mas também os "trás-os-mundos" (PÊCHEUX, 1990). Segundo o autor: "Não há pois, discurso, realmente falado por seres humanos $^{2}$, que possa se destacar completamente dos trás-mundos (ou dos prémundos) que o habitam." (op.cit., p.9)

Deste modo, o anafórico "a cidade", que funcionava para os gregos como um já-dito, e estabelecia um processo de identificação com uma memória histórica (bastava enunciar "Eis Ten Polis" e já se sabia que se tratava de Constantinopla), passa, na formação discursiva dos dominadores (os muçulmanos) a significar algo novo, pois uma atualização da memória se deu quando o enunciado passou a funcionar como nome da cidade.

Deste ponto de vista, ao enunciar "Constantinopla", o sujeito deixa de dizer "Istambul"; e está atualizando, na materialidade lingüística, os dois lados de uma luta política, ao mesmo tempo em que opta pela posição de resistência possível ao dominado.

É necessário, portanto, que o próprio conceito de enunciação seja atualizado para que possa dar conta dessas questões. E encontramos na Psicanálise uma preciosa contribuição ao assunto.

${ }^{2}$ Aqui, Pêcheux está ironicamente se referindo, por oposição aos modelos lógicos, cartesianos de linguagem que seriam os modelos "das máquinas". Diz o autor: "Somente as línguas ideais lógicas podem pretender ater-se a uma distinção estrita dos 'observáveis' - o que aliás, só é possível ao preço da instauração de uma metalinguagem.” (nota 2, p.9) 
Lacan (1998a), criticando o sujeito cartesiano do cogito, afirma que o sujeito pensa antes de ter certeza, e que o correlativo do sujeito é da ordem do Outro enganado. $\mathrm{O}$ autor analisa o clássico paradoxo do mentiroso ("Eu minto") a partir de uma distinção entre sujeito do enunciado e sujeito da enunciação. Diz o autor que, para a Psicanálise, "Eu minto", não se constitui numa antinomia, visto que o "eu" do enunciado é diferente do "eu" da enunciação. Aquele que mente é de fato o sujeito da enunciação, e não o do enunciado. De uma visão psicanalítica, o sujeito da enunciação pretende dizer ao analista "Eu o engano", visto que, para Lacan, toda enunciação fala do desejo de ser aceito pelo Outro e por ele ser amado. Assim, ao pretender enganar o analista, o sujeito é traído pelo inconsciente e se revela, avisando-o do engodo. Mais adiante aprofundarei essa questão, ao falar da repetição e da transferência.

Por enquanto, resta-nos dizer que o sujeito que enuncia "Constantinopla", ao invés de "Istambul", não está meramente fazendo uma escolha entre duas palavras da língua que entram em relação de paráfrase. Este sujeito, nesta posição, está manifestando seu desejo, e, como o desejo, assim como a ideologia, é constitutivamente inconsciente, esse sujeito está sendo colocado em relação ao Outro e à luta de classes em um lugar que procura apagar os traços da história que restaram e ainda significam (pela memória guardada no significante) na palavra "Istambul".

Por outro lado, na outra posição possível (a do dominante), o sujeito que enuncia "Istambul", mesmo sem o saber ("et pour cause") presentifica a memória de que na perífrase "vou para a cidade", temos que "a cidade" é um anafórico que, ancorado na memória histórica, possibilita que não se diga Constantinopla, mas ao mesmo tempo, faz com que o sentido fique implícito. Assim, é o processo de apagamento de um sentido indesejável (o cristianismo) que leva à substituição de Constantinopla por Istambul. O anafórico "a cidade" indicia aí o que se deixou de dizer; algo como: "Vou para aquela cidade que tem o nome impronunciável, mas que você sabe qual é". Não é possível ignorar também nesse processo, a presença da alteridade. Porém, retomando Lacan, temos como resultado que ali mesmo onde o sujeito do enunciado pretende apagar um ou outro sentido, este se revela como engodo, pela enunciação. (Algo, talvez da forma de uma denegação: "Não é para Istambul/Constantinopla que eu vou; é antes para Constantinopla/ Istambul"). Esses "trás-os-mundos" estão ali, presentes pela ausência, latejando na rede da memória. São movimentos na rede de significações possíveis através da língua: apagamentos, substituições, evitações, escolhas lexicais.

Em seguida, continuarei a tentar mostrar (empreendendo uma tarefa arqueológica, tão ao gosto da Psicanálise e da $\mathrm{AD}$ ) que a memória não é 
constituída somente por implícitos que seriam "recuperados" por meio de regras projetivas a partir da interpretação pontual de enunciados efetivamente produzidos (é de notar aqui que esta posição acerca da memória supõe uma anterioridade do dito na produção do sentido, fato bastante discutível, como será, creio eu, apresentado na argumentação que se segue).

Freud (1996a [1925]) em um texto precioso de apenas cinco páginas impressas, é talvez o primeiro a falar da memória como esquecimento, e também como algo que age à revelia do sujeito, e como proteção. Por acréscimo, vemos aí, talvez também pela primeira vez, um uso do termo "escrita" num sentido que escapa totalmente à idéia tradicional que circula ainda hoje, segunda a qual a escrita é a impressão de símbolos gráficos em uma superfície. Freud, aqui, se mostra inteiro como o mestre de Lacan (Outro?), pois neste texto Freud antecipa - muitos anos antes de Lacan escrever que o inconsciente é estruturado como uma linguagem - a relação necessária entre a escrita, enquanto traço permanente (memória) e o funcionamento do aparelho psíquico.

O autor, tentando explicar, através de uma analogia com algum aparelho fabricado pelo homem, como funciona o psiquismo, e que servisse para ilustrar como funciona a memória, descreve o aparato do bloco mágico (uma espécie de brinquedo, que ainda pode ser encontrado, com variações, nos dias atuais) da seguinte maneira:

"O Bloco Mágico é uma prancha de resina ou cera castanhoescura, com uma borda de papel; sobre a prancha está colocada uma folha fina e transparente, da qual a extremidade superior se encontra firmemente presa à prancha e a inferior repousa sobre ela sem estar nela fixada. Esta folha transparente constitui a parte mais interessante do pequeno dispositivo. Ela própria consiste em duas camadas, capazes de ser desligadas uma da outra salvo em suas duas extremidades. A camada superior é um pedaço transparente de celulóide; a inferior é feita de papel encerado fino e transparente. Quando o aparelho não está em uso, a superfície inferior do papel encerado adere ligeiramente à superfície superior da prancha de cera." (op.cit., p. 256)

Mas o que há de tão importante em algo de tão simples funcionamento? Acontece, faz notar Freud, que, após escrever um texto (com um estilete) sobre a superfície de celulóide (esta funciona como camada protetora do papel de seda, que se despedaçaria, caso entrasse em contato direto com a ponta afiada), o sujeito pode apagar o que está na superfície do papel como decalque-escrita, bastando, para tanto, simplesmente que erga com um "puxão leve" as duas folhas, separando-as da superfície de cera.

Até aí, diz Freud, nada distingue esse artefato de outros auxiliares da memória, como uma lousa, por exemplo. Porém, diz o autor, há algo 
admirável no bloco mágico: trata-se do fato de que, após fazer desaparecer a escrita na superfície, ela continua impressa na prancha de cera, e pode ser recuperada, ou relida, "sob luz apropriada" (p.258). Afirma Freud: "Assim, o Bloco fornece não apenas uma superfície receptiva, utilizável repetidas vezes como uma lousa, mas também traços permanentes do que foi escrito, como um bloco comum de papel" (p.258). Para o autor, as duas folhas representariam o aparelho perceptual consciente, e a prancha de cera equivaleria ao inconsciente.

Seria interessante, continua Freud, se fosse possível que o Bloco conseguisse reproduzir "de dentro" aquela escrita que ficou gravada na superfície da cera, visto que deste modo, o artefato reproduziria exatamente o funcionamento da nossa memória. Porém, prossegue o autor:

"Não penso que seja demasiado exagerado comparar a cobertura de celulóide e papel encerado ao sistema Pcpt-cs (perceptual-consciente) e seu escudo protetor; a prancha de cera com o inconsciente por trás daqueles, e o aparecimento e desaparecimento da escrita com o bruxuleio e a extinção da consciência no processo de percepção." (op. cit., p.258)

Estão aí estabelecidas por Freud em apenas cinco páginas, questões cruciais sobre o funcionamento da memória. Temos aí a idéia de que existe uma censura ao processo de recordação: não é tudo, nem qualquer coisa, que afeta a memória do sujeito. Em outras palavras, recordar não é, para Freud, nem um ato consciente, de livre escolha do sujeito, nem um gesto puramente associativo, de fundo neurológico, que leva sinapses a se "acenderem", a partir de um estímulo externo qualquer, ou mesmo de um desejo consciente de busca advindo do sujeito. É importante também notar que algo protege a memória (inconsciente) de funcionar desregradamente. Existe uma proteção, que impede que o sujeito lembre aquilo que vai causar-lhe desconforto ou sofrimento. $\mathrm{O}$ que não significa que, mesmo não sendo conscientemente lembrados, esses conteúdos não "estejam já-lá", e possam retornar de maneira deslocada, visto que a prancha de cera possui camadas superpostas de "escrita", e os lugares desta escrita que vão ser "iluminados" não possuem uma relação direta com o que está na superfície. O esquecimento como proteção do sujeito e o deslocamento, a deriva, de sentido para aquelas regiões do inconsciente que podem aparecer na cadeia manifesta: esse é o mecanismo descrito por Freud. Ou seja, é possível, ao sujeito, através da censura, impedir o processo desenfreado da associação livre (possível por causa da escrita desorganizada do inconsciente) que nos levaria a sítios de significação com os quais não saberíamos lidar saudavelmente.

Derrida (1995 [1967]), comentando o texto de Freud, assim se 
manifesta com relação à colocação acima:

"Se só houvesse percepção, permeabilidade pura às explorações, não haveria exploração. Seríamos escritos, mas nada ficaria consignado, nenhuma escritura se produziria, se reteria, se repetiria como legibilidade. Mas a percepção pura não existe: só somos escritos escrevendo, pela instância em nós que sempre já vigia a percepção, quer ela seja interna ou externa. O 'sujeito' da escritura não existe, se entendermos por isso alguma solidão soberana do escritor. O sujeito da escritura é um sistema de relações entre as camadas: (d)o bloco mágico, do psíquico, da sociedade, do mundo. Não encontramos nessa cena a simplicidade pontual do sujeito clássico.” (p.222)

Do que foi dito acima, podemos fazer surgir duas afirmativas, caras tanto à $\mathrm{AD}$ quanto à Psicanálise:

$1^{\circ}$.- lembrar supõe esquecer;

$2^{\circ}$.- esse processo de esquecimento se instala em virtude de um recalque originário, que é constitutivo do sujeito, através do qual o indivíduo acede ao simbólico.

Vejamos estas questões mais de perto.

A afirmativa segundo a qual lembrar supõe esquecer advém da admissão (e inclusão, na teoria sobre memória) de que o inconsciente existe. Ou, em outras palavras, que o esquecimento também faz parte da interpretação. O processo metafórico, pelo qual o sentido desliza de um sítio de significação para outro, é o fundamento desta máxima. Temos aqui também a regra da $\mathrm{AD}$, segundo a qual "Diz-se x para não se dizer y”, e também aquele silêncio do calar-se, do não-dizer, que Freud (1996b [1914]) afirma ser uma forma de recordar. Para este autor, guardar silêncio diante da regra fundamental anunciada pelo psicanalista ("Diga o que lhe vier à cabeça") é uma resistência contra qualquer recordação, e este é um modo de recordar. Freud afirma ainda que a memória do passado se atualiza de forma deslocada, o que está conforme a regra "dizer x para não dizer y", enunciada acima. Assim, para a Psicanálise, temos que o que se repete é aquilo que se queria esquecer, visto que a repetição substitui (por mecanismo de defesa do inconsciente) o impulso à recordação.

Pode-se fazer uma analogia com a AD, aqui, diante da compulsão à repetição, e dizer que esta denuncia (e enuncia) o sintoma, visto que o processo parafrástico proposto por Pêcheux, produz o efeito metafórico de migração de sentido de uma sequiência para outra, que é enunciada "em seu lugar”, mas cujo sentido é deslocado (ou seja, o não-dito significa).

Retornando ao texto de Freud (1996b), vemos que, para o autor, o sujeito fica desde sempre no esquecimento, e é ao analista que cabe trazer o que é memória (metáfora) do passado para o acontecimento (atualidade), 
através da interpretação, do gesto que vai pontuar a cadeia significante, fazendo com que a mensagem do sujeito retorne para ele de forma invertida, estranhada.

Para a AD, esse processo de recordar e repetir descrito por Freud é explicado (por Pêcheux) de maneira definitiva, através da elaboração dos dois esquecimentos. Não creio que caiba em um trabalho deste porte (supostamente de nível adiantado de reflexão teórica) retomar e repetir cada um deles literalmente. Mas compete-me comentá-los.

Cabe lembrar, como ponto de partida necessário, que, para Pêcheux, o esquecimento no. 1 é constitutivamente inconsciente, é da ordem do recalque, e o esquecimento no. 2 corresponde ao nível pré-consciente (o que está concorde com o que foi proposto por Freud na primeira tópica). O esquecimento no. 1 , ou esquecimento ideológico, por ser inconsciente, é inacessível ao sujeito, e sustenta a ilusão de unidade ("eu sou eu"), visto que o sujeito não se dá conta de que o inconsciente existe, sendo isso já um efeito do próprio inconsciente enquanto interpelação ideológica. Isto, em Psicanálise, está expresso pela colocação da anterioridade do significante ou, como afirma Dor (1992): "A supremacia do significante se traduz, portanto, efetivamente, por uma dominação do sujeito pelo significante, que o predetermina lá mesmo onde ele crê escapar a toda determinação de uma linguagem que ele pensa controlar." (p.45)

Assim, o esquecimento no.1 sustenta a onipotência do sujeito, e o faz crer que ele é a origem do sentido. O esquecimento no. 2 é aquele no qual o sujeito pode penetrar com facilidade, pelo reconhecimento de outras formas de dizer alternativas (famílias parafrásticas), que, ao mesmo tempo em que podem ser alçadas à consciência, sustentam a ilusão da materialidade do pensamento (ou seja: o sujeito crê, por essa ilusão subjetiva, que aquela era a melhor maneira de dizer, e que o enunciado equivale ao seu pensamento).

É irresistível, neste ponto, voltar a considerar a analogia com o bloco mágico proposta por Freud para explicar o funcionamento da memória. Penso que encontramos ali, sob a forma aparentemente simples de descrição do aparato perceptual/inconsciente do processo de armazenagem e recordação, é uma descrição de como funcionam os dois esquecimentos citados: um recalque (no. 1) que não é diretamente acessível, mas "está lá" e retorna sob a forma de repetições, retomadas (sintoma), e um filtro de proteção (no.2) que se presta a controlar o dizer, e não deixar o sentido totalmente à deriva, nem o sujeito a céu aberto (o que é próprio da psicose). Os dois esquecimentos colocam, no plano lingüístico-ideológico (discursivo, portanto), a necessidade de se postular que a $\mathrm{AD}$ “(...) considera a noção de sujeito dividido, que pode ser uma forma de tratar a heterogeneidade, pois a noção de sujeito dividido leva em conta o fato de 
que sob as palavras há outras palavras, há o discurso do inconsciente." (TFOUNI, 2003, p.96)

Podemos fazer seguir daí, levando em consideração que há um primado, uma relação de dominância (cf. PÊCHEUX e FUCHS, 1993) do não afirmado sobre o afirmado, de tal modo que a memória (na forma do interdiscurso) precede e determina, à revelia do sujeito, sem que ele se dê conta disso, os enunciados que ele produz.

Temos, assim, que o sintoma do sujeito, aquilo que ele repete e é fonte de gozo para ele (talvez por isso mesmo), esse sintoma é causado pela interpelação ideológica.

Ora, outra máxima da $\mathrm{AD}$ advém do próprio conceito de ideologia, que implica um não-querer-saber (visto que o sintoma é o gozo), e, como se sabe, a ideologia decorre do estado da luta entre as classes em conflito uma com a outra, e um processo de apagamento/identificação do sujeito de/com um ou outro lugar dentro dessa luta, o que vai determinar as sequiências produzidas/esquecidas pelo sujeito. Assim, temos que a desigualdade, produto da luta de classes, está inscrita na língua, e que o real da língua, aquela parte traumática que nunca se mostra totalmente mas faz um retorno constante sob a forma das paráfrases/metáforas, esse real é em última análise determinado pelo real da história (que, segundo ZIZEK (1996), é a luta de classes).

Temos aqui algo explosivo com o qual lidar. Na verdade, trata-se da negação da existência de dois reais, tal como tem feito a $\mathrm{AD}$, principalmente através da obra de Gadet e Pêcheux (1981), na qual os autores, comentando a questão proposta por Lacan e perfilada por Milner de que o único real é o real da língua, retrucam afirmando que, além do real da língua devemos considerar também o real da história:

"Em appui contradictoire sur cette thése de Milner, nous avons tenté ici de faire travailler le réel de l’histoire comme une contradiction d'oú l'impossible ne serait pas forclos. (...) C'est em même temps le point ou nous nous separons politiquemente de lui, sur la question du matérialism historique. Que Milner ne consente pas, aujourd hui, a concevoir l'histoire autrement que sous la forme parodique d'un materialisme de synthése, narcissique et aveugle, dans lequel l'histoire ne peut avoir que la forme d'un development synthétique progressif de la conscience et qu'il lui dénie en conséquence tout réel, c'est lá une tout autre affaire." (op. cit., p.50)

Acredito que enfraquece a teoria da $\mathrm{AD}$ postular-se uma taxonomia do real, como tenho visto, depois de Gadet e Pêcheux, alguns autores fazerem (falam, por exemplo, no "real da significação"). Ora, o real é irredutível ao plural. O real é O REAL; assim mesmo, tautológico e redundante, pois só 
pode reduzir-se a si mesmo. O real é de uma outra ordem. É o impossível e o contingente; é aquilo que não pode não ser de outro jeito. Como, então, dar conta de dois ou mais reais? A crítica que Gadet e Pêcheux (op. cit.) fazem a Milner está centrada na questão de que, para Milner, esse real, cujas categorias são impossível e o contingente, se exprime pela regra segundo a qual "não se pode tudo dizer", mas ao mesmo tempo ele coloca a lalangue como quase uma categorização da língua, uma topografia, onde poder-se-ia falar sobre o que não pode ser dito. O que vemos ressurgir aí é quase uma retomada da clássica divisão entre Gramática e Retórica, visto que Milner, segundo Gadet e Pêcheux (op.cit.), postula um materialismo de síntese, oposto a um materialismo dialético, que (este último) não pode deixar de considerar a história como produtora dos processos de significação.

A proposta que faço aqui é que, seguindo Zizek (op.cit.), a língua deve ser estudada (tanto na Psicanálise quanto na $\mathrm{AD}$ ) não enquanto sistema (o que significa a morte do acontecimento) mas enquanto produto da luta de classes, e, nesse sentido, enquanto produto da inscrição da história (memória do dizer, fatos, temporalidade) na língua. Assim, o real da história é o que faz a língua funcionar, gerando o acontecimento. Ou seja, o real só pode operar na enunciação, quando o sujeito diz x para não dizer y, sob o efeito do esquecimento no.1, do recalque originário, preço pago para aceder ao simbólico, e que faz o sujeito ser dividido entre um "eu" (consciente) e algo que o assujeita (inconsciente).

A noção de interdiscurso permite trazer para a AD uma história não cronológica. Uma história onde está inscrita a contradição, e que captura o sujeito em uma teia (já-lá) de significações, fazendo-o inscrever-se, à sua revelia, em uma formação discursiva, no mesmo movimento em que "se esquece" de que as palavras que ele (sujeito) "pensa" escolher livremente, já estão dotadas de sentido, e só por isso significam. As relações de paráfrase e o efeito metafórico, que coexistem, enquanto virtualidade, com uma sequiência manifesta, atestam que a história está ali. Foi isso que mostrei para o uso de Istambul/Constantinopla. Ou seja: a determinação dos processos semânticos é histórica, e a enunciação se faz como acontecimento, e não como pontualidade em uma cadeia significante qualquer.

É interessante notar aqui que esse mecanismo de naturalização que captura o sujeito não se restringe à escolha de um léxico.

$\mathrm{O}$ acontecimento assume as feições da verdade do sujeito. Assim, as formações metafóricas, que concretizam a deriva (origem do acontecimento) inserem-se também na história particular, ou seja, na memória do sujeito. Deste modo, as atualizações na língua, são produto da história social e da história particular, as quais possibilitam ao sujeito alocar-se em sítios de significação (materializados em cadeias de significantes), lugares 
específicos no interdiscurso, onde o sujeito vai ancorar-se.

Deste modo, é um engano supor, à maneira da semântica formal, que as palavras têm um sentido porque têm um referente, e que palavras diferentes que possuem o mesmo referente estão em relação de sinonímia. O caráter da equivocidade da língua (que faz com que o sentido sempre possa vir a ser outro, quer pelas cadeias parafrásticas, quer pelo efeito metafórico), no entanto, confere uma imprevisibilidade a esse processo, de tal modo que nunca se pode prever o rumo da significação, nem é possível fazer a interpretação caminhar em linha reta.

Meio às avessas, na contramão desta posição, e marcando a presença da história (e da memória) na construção de um efeito de sentido, apresento o seguinte recorte, retirado de uma entrevista realizada com uma mulher grávida.

Vejam os leitores o significante "cachorro", tal qual foi empregado no recorte abaixo, que retirei do corpus colhido por uma orientanda, Glaucimara de Freitas e Silva, cuja pesquisa de mestrado teve por tema o discurso de mulheres grávidas em situação de risco (ver FREITAS E SILVA, 1999, para maiores informações sobre este trabalho).

O sujeito S., grávida de sete meses (quarta gestação; dois filhos; sofre de pressão alta), entrevistada em sua casa, tinha na época um cachorro, que foi trancado no corredor em frente à porta da cozinha, para facilitar a realização da entrevista. Este cachorro ficou latindo muito e tentando entrar o tempo todo.

O seguinte diálogo aconteceu em um dado momento entre o sujeito $\underline{(S)}$ e a entrevistadora $(E)$ :

"E: Vem cá, você conversa sobre o nenê com outras pessoas?

S: Assim, com a família eu não converso, não.

E: E por quê?

$\mathrm{S}$ : Com o marido também não. Ah, porque eles são muito agressivo; sabe, eles não te dão uma chance pra você fala o que você qué; eles acham que você só tem que ouvi, entende? Que nem hoje cedo; eu falei pro meu marido: "eu tô entrando no sexto mês e não parei de trabalhar, sendo que a médica já me afastou." Aí, ele virou pra mim gritou e falou assim: "É? Você qué o quê? Você não come? Você vai trabaia até o dia de tê; a minha mãe trabaiô na roça e teve nóis no meio do pé de café". 
Bom, aí já fiquei sabe.... Olha o cachor-

ro!" (op.cit., pp. 128-129)

Como deve ser entendido aí o enunciado "Olha o cachorro"? Qual o sentido de "cachorro" aí? Do ponto de vista de uma semântica formal, poderíamos dizer que " o cachorro", no enunciado, refere-se ao cachorro que está latindo no corredor, uma vez que o sujeito, na situação de diálogo, está nomeando ostensivamente um referente do "mundo real" para seu interlocutor. Porém, se perseguirmos o fio significativo do discurso, a forma como o marido está sendo apresentado discursivamente pelo sujeito, através dos significantes "agressivo", "não dá uma chance pra você falá", "gritou", "você não come?", cabe também a interpretação segundo a qual "cachorro" é a metáfora do marido. Maneira deslocada de referir-se, só possível pelo caráter de equivocidade da língua, advindo do fato de que os significados não aderem permanentemente aos significantes. Esta última observação leva a discussão para o conceito de ponto-de-estofo, utilizado por Lacan (1998b). Este autor propõe a noção de ponto-de-estofo quando discute o corte saussuriano entre significante e significado à luz do que lhe advém da experiência analítica. Lacan define este conceito (ou operação) como o modo pelo qual “... o significante detém o deslizamento, de outra forma indeterminado e infinito, da significação" (op. cit., p.10). Estas amarrações feitas na cadeia da fala ocorrem de maneira retroativa, de tal modo que, como diz Lacan: "Vocês só encontram a função diacrônica desse ponto-de-estofo na frase, na medida em que esta só fecha sua significação com seu último termo, cada termo sendo antecipado na construção de todos os outros e, inversamente, selando seu sentido por seu efeito retroativo" (op.cit., p. 10). Fora da possibilidade de fazer ponto-de-estofo, o sujeito fica "a céu aberto", não é capaz de controlar seus pensamento e associações e delira, como na psicose (foraclusão). Dor (1992) comenta essa operação de controle do fluxo significante da seguinte maneira:

"Identificamos aqui uma referência direta ao problema do valor do signo, analisado por F. de Saussure. Cada signo só é significativo na relação de oposição que mantém com todos os outros signos da seqüência falada. Podemos adiantar, portanto, como faz Lacan, que é sempre retroativamente que um signo faz sentido, na medida em que a significação de uma mensagem só advém ao final de sua própria articulação significante (....) dito de outra forma, é na dimensão da posteridade que o ponto-de-estofo detém o deslizamento da significação." (p. 40)

No recorte da fala de $\mathrm{S}$. que foi apresentado acima, está manifesta essa operação. O sujeito, inicialmente, fala da família; logo em seguida do marido, e depois inicia uma seqüência onde ocorrem várias indeterminações de sujeito: "eles são muito agressivos"; "eles não te dão uma chance", 
"eles acham que você só tem que ouvir". Logo em seguida, menciona o marido novamente, "atuando" para a interlocutora, na forma do discurso direto, o diálogo no qual foi extremamente maltratada pelo marido. Em seguida, quando vai falar sobre seus sentimentos ("Bom, aí já fiquei, sabe....), seu "pensamento" como que se desvia do plano do enunciado (da pura memória) para a enunciação, e o sujeito diz: "Olha o cachorro!".

Assim, nesse movimento de "dizer x para não dizer y", vemos a memória se atualizando em acontecimento, permitindo ao sujeito falar de sua dor, seus medos, suas angústias, de maneira deslocada, e sem se dar conta do verdadeiro efeito de sentido que está produzindo. Somente o trabalho interpretativo do analista pode trazer ? para a aparente transparência semântica dos enunciados ? as palavras sob as palavras, revelando, no caso, o efeito metafórico. Vemos aí também, a evidência de que lembrar supõe esquecer (lição que nos chega também por caminhos de releitura através do conceito de valor de Saussure). Ou seja, foi preciso que o sujeito se "esquecesse" de que estava reclamando do marido na cadeia manifesta e "sem se dar conta", voltasse sua atenção para o cachorro que latia, para, deste modo, metaforicamente, reclamar dos maus tratos que recebia.

O processo que permitiu trazer luz a esse recorte foi o reconhecimento, por parte desta analista, de que existe uma memória constitutiva - o interdiscurso - que possibilita a retomada deslocada do já-dito, assim como uma memória social, constituída pelas coisas a saber (o "arquivo"). Do lado da língua, é necessário que o analista aceite a postulação da "lalangue", onde se torna possível o equívoco, o efêmero, o acontecimento.

Continuando a análise do recorte, temos que "cachorro" desliza de "animal" para "marido" por força do esquecimento no. 1, ou seja, sem que o sujeito se dê conta. Assim, a metáfora, o deslize, característico da lalangue permite ao sujeito falar sobre o que está interditado, proibido radicalmente, por força da ideologia e do recalque: o desejo se manifesta à revelia, sob a forma da repetição (no recorte em análise, o retorno do significante "cachorro" deu-se por repetição algumas vezes antes, enquanto o sujeito reclamava dos latidos e o colocava para fora). Este é o acontecimento, efeito metafórico descrito pela fórmula "dizer x para não dizer y", e que Pêcheux (1999) descreve da seguinte maneira, comentando Achard (op.cit.):

“(...) segundo Achard, essa regularização discursiva, que tende assim a formar a lei da série legível, é sempre suscetível de ruir sob o peso do acontecimento discursivo novo, que vem perturbar a memória: a memória tende a absorver o acontecimento, como uma série matemática prolonga-se conjeturando o termo seguinte em vista do começo da série, mas o aconteci- 
mento discursivo, provocando interrupção, pode desmanchar essa regularização e produzir retrospectivamente uma outra série sobre a primeira, desmascarar o aparecimento de uma nova série, que não estava constituída enquanto tal e que é assim o produto do acontecimento; o acontecimento, no caso, desloca e desregula os implícitos associados ao sistema de regularização anterior." (p.52)

Penso, com relação ao texto de Pêcheux acima citado, que ele foi além na leitura que fez de Achard, na medida em que se identifica com e se reconhece em Achard, colocando neste último quase a autoria da noção de acontecimento, que, como todos sabemos, é do próprio Pêcheux. Por este motivo, considero as palavras usadas pelo autor para comentar Achard como palavras próprias, no sentido bakhtiniano do termo.

Quero atrair a atenção do leitor para o significante "retrospectivamente", que aparece na citação acima. Minha intenção é aproximar seu sentido, no trecho, do sentido de "retroação", já apresentado atrás, e tão caro à Psicanálise lacaniana.

Em Psicanálise, é o processo de retroação, de retorno à cadeia significante (muitas vezes em decorrência de uma pontuação do analista) que permite ao sujeito "amarrar" um significante - que aparentemente é inofensivo e inócuo - a um sítio específico de significação que tem a ver com algo recalcado de sua memória/história particular. Daí advém uma nova leitura da cadeia manifesta, ou, como afirma Pêcheux: “... sob o "mesmo' da materialidade da palavra abre-se então o jogo da metáfora, como outra possibilidade de articulação discursiva... Uma espécie de articulação vertical, em que a própria memória esburaca-se, perfura-se, antes de desdobrar-se em paráfrase." (op. cit., p. 53)

Para finalizar, retomo os conceitos de efeito metafórico e paráfrase, para comentar brevemente algo muito precioso para o analista do discurso: a natureza do recorte.

Ao contrário do que se poderia pensar, a metáfora não é necessariamente somente a repetição ou a retomada de palavras, nem a paráfrase é apenas a repetição ou a retomada de enunciados.

O acontecimento pode advir sob a forma de "retalhos", fragmentos, nacos esgarçados da língua, às vezes confundidos pelos menos avisados, com "erros gramaticais", como será mostrado no recorte abaixo, retirado da redação de um universitário, cujo titulo é “As Duas Almas”. (Faço notar que o corpus de onde retirei este recorte foi coletado por Soraya Maria Romano Pacífico, que o utilizou em sua tese de doutorado (PACÍFICO, 2002):

"Entretanto, precisamos consolidar estas duas almas, que independem uma da outras ( sic!) mas não se vive sem elas. Nos completa- 
mos e nos "formamos" através delas, por isso, devemos saber e respeitar as duas para que não nos perdemos como Jacobina." (op.cit., p. 137)

A troca do subjuntivo ("percamos") pelo indicativo ("perdemos") indicia, do ponto de vista das questões que estou tratando aqui, que o sujeito não consegue encontrar um lugar a partir do qual possa construir hipóteses (cuja modalidade é o subjuntivo). Assim, não é ao acaso que o inconsciente pontue exatamente o verbo "perder" (oposto de "encontrar"), e que o modo indicativo (o modo da certeza, dos fatos) seja utilizado ali onde deveria, pela ordem da língua, aparecer um subjuntivo. Temos aí, escancarado, o trabalho da memória, que atualiza em um aparente "erro gramatical" toda uma história de incapacidade e fracasso da escola, que não consegue ensinar os alunos a argumentar com base em hipóteses e conjeturas. O que retorna aí é uma confissão de falência do ensino, que o sujeito "diz" sem se dar conta disso: "Eu sou ali onde não penso", como diz Lacan.

A lição metodológica que se pode tirar dessa análise é que o analista, para analisar, precisa tomar o recorte como uma seqüência solta de significantes que só terá um sentido quando devidamente iluminada pela memória, enquanto interdiscurso e história, e pela língua em funcionamento.

\section{BIBLIOGRAFIA}

ACHARD, Pierre. Memória e produção discursiva do sentido. In: ACHARD, Pierre et alli. Papel da memória. Campinas, Pontes, 1999.

DERRIDA, Jacques. A escritura e a diferença. São Paulo, Perspectiva, 1995.

DOR, Joel. Introdução à leitura de Lacan - v.I. Porto Alegre, Artes Médicas, 1992.

FREUD, Sigmund. Uma nota sobre o 'Bloco Mágico'. In: __. O ego e o $i d$. Edição Standard Brasileira das Obras Completas de Sigmund Freud .v. XIX. Rio de Janeiro, Imago, 1996a.

FREUD, Sigmund. Recordar, repetir e elaborar (Novas recomendações sobre a técnica da Psicanálise II). In: _. O caso de Schreber e Artigos sobre técnica. Edição Standard Brasileira das Obras Completas de Sigmund Freud. v.XII. Rio de Janeiro, Imago, $1996 \mathrm{~b}$.

FREITAS E SILVA, Glaucimara. A materialidade do desejo: Análise do discurso de mulheres grávidas. Programa de pós-graduação em Psicologia, Departamento de Psicologia e Educação, FFCL RP, Universida- 
de de São Paulo, Ribeirão Preto, 1999. Dissertação de mestrado

GADET, Françoise \& PÊCHEUX, Michel. La langue introuvable. Paris, Maspero, 1981.

LACAN, Jacques. Os quatro conceitos fundamentais da Psicanálise -o Seminário livro 11.Rio de Janeiro, Jorge Zahar, 1998a.

LACAN, Jacques. Subversão do sujeito e dialética do desejo no inconsciente freudiano. In:__. Escritos. Rio de Janeiro, Jorge Zahar, 1998b.

PACÍFICO, Soraya Maria R. Argumentação e autoria: o silenciamento do dizer. Programa de Pós-Graduação em Psicologia, Departamento de Psicologia e Educação, FFCLRP/USP, Ribeirão Preto, 2002. Tese de doutorado.

PÊCHEUX, Michel. Ler o arquivo hoje. In: ORLANDI, Eni P. (org.) Gestos de leitura: da história no discurso. Campinas, Ed. da Unicamp, 1997.

PÊCHEUX, Michel. Delimitações, inversões, deslocamentos. Campinas, Cadernos de Estudos Lingüísticos, n. 19, p. 7-24, jul./dez. 1990.

PÊCHEUX, Michel \& FUCHS, Catherine. A propósito da Análise Automática do Discurso: atualização e perspectivas (1975). In: GADET, Françoise; HAK, Tony (orgs.). Por uma análise automática do discurso - Uma introdução à obra de Michel Pêcheux. Campinas, Ed. da Unicamp, 1993.

PÊCHEUX, Michel. Papel da memória. In: ACHARD, Pierre et alli. Papel da memória. Campinas, Pontes, 1999.

TFOUNI, Fábio Elias Verdiani. A linguagem e o sintoma na análise de slogans: A fetichização da mercadoria. FFCL, UNESP, Araraquara, 2003. Tese de Doutorado.

ZIZEK, Slavoj. O espectro da ideologia. In: ZIZEK, Slavoj (org.). Um mapa da ideologia. Rio de Janeiro, Contraponto, 1996. 